\title{
Surprise after surprise - A preface of the editor
}

At the end of the assembling this Special Issue in August 2021, the $11^{\text {th }}$ of its kind ${ }^{1}$, it is not yet clear whether the worldwide use of the designation COVID-19 is appropriate. There are some indications that the first cases of the new type of coronavirus may have occurred before 2019 and, more importantly, it is not known whether this deadly disease affects calendar years 2020 and 2021 or whether 2022 will be a pandemic year, too. All we know for sure is that when the WHO declared the outbreak a Public Health Emergency of International Concern on 30 January 2020, no one thought that it would hit the economies of every country on Earth hard. The medical problem initially appeared to have only a public health dimension.

There is a famous phrase in Marx's Capital that all macroeconomists, regardless of their worldview, have always regarded as trivial: "Whatever the form of the process of production in a society, it must be a continuous process, must continue to go periodically through the same phases. A society can no more cease to produce than it can cease to consume. When viewed, therefore, as a connected whole, and as flowing on with incessant renewal, every social process of production is, at the same time, a process of reproduction." ${ }^{2}$ That in peacetime the governments of most countries in the world would be willing to halt production by administrative fiat - that is, with the deliberate intention of reducing GDP and increasing unemployment - was utterly inconceivable.

\footnotetext{
${ }^{1}$ The first occasion, back in 2004, was linked to a memorial conference devoted to Hungarian - American economist John von Neumann (1903-1957) on his $100^{\text {th }}$ birthday. After a 10 -year long break, the second special issue covered the $25^{\text {th }}$ Anniversary of the Post-Socialist Transition. It was essentially a celebratory collection of 8 papers with a strong emphasis on the historical economic achievements and the surprising peaceful political transition from central planning to market economy. The third publication carried a more sober title, "Transition Economies in Trouble". With 9 commissioned papers, we covered 14 countries. Our sad conclusion was that the catching-up process for these economies has turned out to be much slower than generally expected. Furthermore, and not independently from the economic performance, many countries have failed to create a democratic political system. In 2016, our chosen topic for the fourth occasion was "Grexit, Brexit - The future of the European Economic Integration" - a sensitive, unfinished story described and analyzed by 8 authors. The fifth Special Issue was a celebration again, not of an event, but of a person, the Hungarian-born, British economist, (Lord) Nicholas Kaldor (1908-1986). That volume and an international conference in Budapest a year earlier marked the $30^{\text {th }}$ anniversary of Kaldor's death. Of the conference material, 11 papers were selected and re-edited for publication in Acta Oeconomica. The sixth Special Issue which came out in January 2018, was devoted to the $90^{\text {th }}$ birthday of János Kornai, the best-known and most revered Hungarian economist of all times. The seventh Special Issue tried to prove that 2008 international financial crisis was at the end merely a notso-devastating recession and the mechanism of globalized capitalism remains highly functional, as most mainstream economists agree. In 2019, we managed to publish two Special Issues, one to celebrate the $70^{\text {th }}$ birthday of our respected Polish colleague in our International Advisory Board, Grzegorz W. Kolodko, and another one from studies on the internationalization of Central and Eastern European firms. The $10^{\text {th }}$ thematic volume was devoted to the spectacularly rising economy of China.
}

${ }^{2}$ Marx, Karl: The Capital, Vol. I. Ch. 23. Simple Reproduction. 
And yet that is exactly what happened, when the "lockdown" and "stay-home" orders were legislated in the big countries - think of the United States or China, but also in small countries like Luxembourg or Kosovo.

Then came four more surprises. The first two were gratifying. Effective vaccines were produced much more quickly than expected - practically within a year and in several countries parallelly. It proved that, in the globalised world economy, competition and cooperation between multinational pharmaceutical companies can work effectively, and that, in times of great need, there is unprecedented flexibility in the way private pharmaceutical companies and the state machinery can work together, both nationally and globally. Second, it was reassuring for academic researchers, professors of 101 university courses in economics to see that short-term business cycles can be sufficiently well explained by external shocks rather than invoking the doomsday theories about the intrinsic and ever-deepening contradictions of the capitalist, market economies. What on Earth can be a more convincing example for an external shock than a medically contagious, totally new viral infection?

Then the third surprise was a very bitter one. It is precisely in recent weeks that it has become clear that vaccination is not a perfect barrier against the ever-mutating SARS-CoV-2 virus. ${ }^{3}$ The fourth surprise is actually not a surprise at all, if we think in terms of the Marx quote, I mentioned earlier. It turns out that the pandemic needs not (and cannot) trigger a prolonged recession in the world's leading countries. In the US, for example, the recession lasted only two months. In a recent consensus report, the Business Cycle Dating Committee of the National Bureau of Economic Research (NBER) concluded that the unprecedented magnitude of the decline in employment and production, and its broad reach across the entire economy, warranted the designation of this episode as a recession, even though the downturn was briefer than earlier contractions. The NBER determined that a trough in monthly economic activity occurred in the US economy in April 2020. The previous peak in economic activity occurred in February 2020. Thus, the recession lasted two months, which makes it the shortest US recession on record. ${ }^{4}$

Most of the papers in this volume were commissioned by the Editor-in-Chief of this journal. As usual, some invited authors failed to meet the deadline, despite promises to do so, while others found out about the special issue indirectly through Acta Oeconomica's website. In the end - and no surprise - more than 30 manuscripts were received that could have been included in the volume in terms of quality. However, the volume limit was insurmountable, thus only 11 manuscripts were accepted.

\footnotetext{
${ }^{3}$ Severe Acute Respiratory Syndrome Coronavirus-2 is the WHO-catalogized name given to the 2019 novel (corona) virus. COVID-19 is the name given to the disease associated with this new virus. For virologists it is known for decades that coronaviruses are circulating among animals, and a limited type of them can infect humans. For example, bats, camels, civet cats etc. are considered natural hosts of these viruses. SARS-CoV-2 is a new strain of coronavirus that has not been previously identified in humans. After two years of intensive research, it is still a known unknown how, where and when this highly contagious virus jumped from animals to humans.
}

${ }^{4}$ https://www.nber.org/news/business-cycle-dating-committee-announcement-july-19-2021. 
The editorial team tried to meet multiple demands at once. The aim was to allow several authors to explore some issues with different approaches. Obviously, we have also sought to ensure that as many authors of different nationalities as possible are represented, and to give health economists the opportunity to contribute their views to complement the macro-economic approach. After all, COVID is a medical challenge in the first place.

We knew in advance that we would be shooting at a moving target. We hope to get many valid hits from the 11 articles. Papers that will attract the interest of the profession and will be referred to many and many times in the years to come.

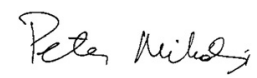

Editor-in-Chief 